\title{
ANTIFUNGAL ACTIVITY OF TWO PLANT EXTRACTS AGAINST Fusariun solani AND Rhizoctonia solani, THE CAUSAL PATHOGENS OF STEM AND ROOT ROT DISEASES OF POTHOS ( Epipremnum aureus ). EL Morsy, S. A. ; Naglaa T. Mohamed and A. S. Ibrahim. Plant Pathol. Res. Inst., Agric. Res. Center, Giza, Egypt .
}

\begin{abstract}
Organic solvent extracts of lemon grass leaves were more effective than those of rhubarb roots in inhibiting mycelial growth of $F$. solani and $R$. solani, two fungi pathogenic to pothos plants causing root and basal stem rots. Superiority was realized as for ethanolic extracts than those extracted using hexane and ethyl acetate as organic solvents .

Dipping root system of pothos cuttings in $20 \%$ concentration of ethanolic extracts of lemon grass or rhubarb for $15 \mathrm{~min}$. just before planting in soil infested with either of $F$. solani and $R$. solani recorded the lowest percentages of diseases incidence by $(5 \% \& 10 \%)$ and $(15 \% \& 20 \%)$, respectively , relative to those of their controls ( $40 \% \& 60 \%$ ) .

Values of physical characteristics of lemone grass essential oil such as specific gravity $(0.89 \%)$, optical rotation ( -1.6$)$, refractive index ( 1.4875$)$ and acid number ( 8.3 ) were estimated. Also, chemical main compounds quantitatively determined by chromatography which confirmed that volatile matter of lemon grass oil represents $100 \%$ of its composition. However, citral and myrecene constituted 77.0 $\%$ and $6.5 \%$ of the total composition of that oil .

Lemon grass essential oil at concens. of $10 \%$ and $20 \%$ could completely inhibit mycelial growth of the aforementioned two fungi, respectively .Besides , citral ( 2.5 concen. ) realized the same effect, whereas, myrecene only minimized mycelial growth of these fungi by $40 \%$ and $28.6 \%$.
\end{abstract}

\section{INTRODUCTION}

Root and basal stem rots as soilborne fungal diseases caused by $F$. solani and $R$. solani have been considered the highly destructive diseases affecting pothos ( Epipremnum aureus ) plants in Egypt and other countries resulting in great losses in respect to that ornamental foliage plant ( Chase , 1987 and El-Morsy, 2000 ).

Root-dip treatment using certain fungicides has been applied as the only method for controlling such diseases ( El-Morsy , 2000 ), but new tools to minimize the fungal pathgenicity are highly needed since their causal pathogens usually used to develop resistant or tolerant fungi to common fungicides and to avoid environmental pollution .

Plant diseases management with plant natural products evidently provide a wide public acceptance as alternatives to synthetic fungicides because of the relatively high cost of developing a new fungicide and the less negative impact either on environment or on fungal resistance to fungicides . 
Many higher plants and their constituents gave a considerable control of some plant diseases and provided safety and non-phytotoxicity unlike chemical fungicides. In the last two decades, intensive studies were reported including substances derived from plant origin as environmental safe pesticides. Multi harvest lemon grass leaves (Cymbopogon citratus) is a medicinal and aromatic source of volatile compounds used commercially in pharmaceutical and allied industries ( Ashrafuzzaman et al., 1990 ; Shimoni et al. , 1993 ; Ansari , 1995 ; Valari et al. , 1996 ; Wood et al. , 1997 and Baratta et al. , 1997 . Also, ethanolic extract of rhubarb ( Rheum oficinale ) roots was reported as a formulated aqueous solution named Physcion ( Yang et al. , 2009 ). Moreover , essential oils extracted from certain medicinal and aromatic plants were reported to contain volatile aromatic compounds which possessing antifungal activities ( Soliman \& Badeaa , 2002 ).

This investigation mainly aimed to determine the possible antifungal effects of lemon grass and rhubarb organic solvent extracts against $F$. solani and $R$. solani, two fungi pathogenic to pothos. Inhibitory effect of these extracts, different concentrations of lemon grass essential oil as well as the two main active components of this oil on mycelial growth of the two fungi tested was investigated. This study also included the evaluation of effectiveness of lemon grass and rhubarb ethanolic extracts on diseases incidence $(\%)$ caused by the two fungi .Some properties of lemon grass essential oil were estimated. The major constituents of lemon grass oil were separated and identified by Gas Chromatography method using appropriate detectors.

\section{MATERIALS AND METHODS}

Two purified and identified isolates of Fusarium solani ( Mart.) Sacc. and Rhizoctonia solani Kühn , previously confirmed their pathogenicities to pothos plants causing stem and root rots, were used in all experiments in this study . 1.Plant materials and extraction with organic volatile solvents:

Lemon grass leaves and rhubarb roots were obtained from Medicinal and Aromatic PI. res. Sta. , Hort. Res. Inst. , Agric. Res. Center at El-Kanater El-Khairyia，Qalubyia governorate. Fifty grams of finely grounded air dried leaves or roots of the previous plants, respectively, were separately soaked for $48 \mathrm{hrs}$. in one liter of the organic solvents tested, i.e. ethanol, hexane or ethyl acetate. The mixtures were filtered through filter paper Wattman ( 1 ). The solvents were evaporated using rotary evaporator under the suitable temperature for each one. The resultant residues were dissolved in $96 \%$ ethanol, then kept in a refrigerator at $5{ }^{\circ} \mathrm{C}$ for further studies. At the experimental time, ethanol was evaporated and the residues were dissolved in one liter of distilled water and sterilized by Seitz's filter ( Kshirsagar and Mehta , 1972 ) .

2. Inhibitory effect of three organic solven extracts on mycelial growth of the two fungi tested :

The previous three organic solvent extracts of lemon grass leaves and rhubarb roots were separately mixed with sterilized PDA medium in flasks 
just before solidification, then poured into sterilized Petri dishes. Medium free from extracts but provided with the same volume of sterilized distilled water were used as control treatment. As regards plates with extracts or those of control, four replicates ( plates ) were inoculated at the center with fungal discs ( $5-\mathrm{cm}$ - diam. ) cut from 7 - days - old culture of each fungus tested, then incubated at $26{ }^{\circ} \mathrm{C} \pm 2$. The linear growth of each particular treatment was recorded when mycelial growth filled any plate of its control treatment. Antifungal inhibition was expressed as percentage of reduction in mycelial growth relative to linear growth in control plates .

3. Effect of lemon grass essential oil (different concens, ) and its main component ( $2.5 \%$ concen, ) on mycelial growth of the two fungi tested :

Procedures of preparing the essential oil of lemon grass leaves were conducted according to bioassay method reported by Brock and Brock ( 1973 ) . Eight concens. Of this oil , i.e. $2.5 \%, 5.0 \%, 10.0 \%, 20.0 \%, 30.0$ $\%, 40.0 \%, 50.0 \%$ and $60.0 \%$ ) were prepared by diluting the crude oil with sesame oil as a solvent (Radwan, 2001). Punched discs ( 5 - mm - diam.) of filter paper Wattman No. ( 1 ) were placed into closely screw capped bottles ( 100 discs / bottle ) and sterilized in oven at $140{ }^{\circ} \mathrm{C}$ for $60 \mathrm{~min}$. , then allowed to cool down to the room temperature. The cooled discs were separately immersed in the eight concens. of essential oil , the dried by placing the container of discs in water bath at $50^{\circ} \mathrm{C}$ with occasional shaking to mix and allow even distribution of oil between discs till complete absorption of oil and dryness of discs by entire evaporation of the solvent . Control discs were immersed in sesame oil and dried as previously mentioned. As for citral and myrecene ( the main components of lemon grass essential oil ), sterlized punched discs ( 5 - mm - diam. ) of filter paper Wattman No. (1) were separately saturated with 2.5 concen. of these components, whereas those of control were saturated with sterilized distilled water . For each oil cocen. or its control as well as any of the main components and their controls, PDA plates were inoculated at the center with discs ( $5-\mathrm{mm}$ - diam. ) at the rate of one disc a plate cut from 7 - days - old of the two fungi tested, the inverted and the saturated filter paper discs were placed into their lids ( 4 discs / plate ). Four plates were used for each particular treatment, then plates were incubated at $26{ }^{\circ} \mathrm{C} \pm 2$. Linear growth was measured and percentages of inhibition in mycelial growth as follows :

$$
\text { Inhibition }(\%)=\frac{\text { A }-B}{---} \quad \text { A } 100 \text { where : }
$$

$A=$ Linear growth of control . $B=$ Linear growth of treatment .

4. Effect of lemon grass and rhubarb extracts on diseases incidence (\%) under greenhouse conditions :

Formalin - sterilized plastic pots ( $20-\mathrm{cm}$ - diam. ) were packed withed formalin - sterilized soil mixture constituted from peat moss and sand $(1: 1$, $\mathrm{v} / \mathrm{v})$. Pots were separately infested with corn - meal sand inocula of $F$. 
solani or $R$. solani at the rate of $3 \%$ soil mixture ( $30 \mathrm{gm}$ inoculum / $\mathrm{Kg}$ soil ) seven days before planting cuttings. Three concens. of lemon grass ( leaves) and rhubarb (roots ) ethanolic extracts, i.e. $5 \%, 10 \%$ and $20 \%$, were used in this study. Root system of pothos rooted cuttings ( 30 - days - old) were separately dipped for $15 \mathrm{~min}$. in either of the three previous concens. for each extract or in water only ( control treatment) just before planting in infested soil . For each particular treatment, 4 replicates (pots) were used and each pot was planted with 10 cuttings. Percentages of diseases incidence were recorded 21 days after planting as follows :

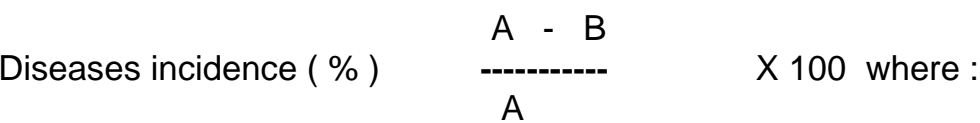

\section{$A=$ Percentages of infected cuttings in control ( infested soil planted with untrated cuttings ). \\ $B=$ Percentages of infected cuttings in treatment (infested soil planted with trated cuttings ).}

\section{Determination of physical and chemical properties of lemon grass essential oil :}

Refractive index, specific gravity, optical rotation and number of acid value of lemon grass essential oil were determined according to the method described by Guenther ( 1961 ) using Abbe refractometer Zeiss model II , a pycon meter ( $5 \mathrm{ml}$ capacity) , Zeiss polarimeter for the three former criteria, respectively .

Identification of the chemical of the essential oil was processed by GC/MS method using asset of authentic volatile compounds representing different chemical groups ( $99 \%$ purity ) of Kato Aromatic Co. Standard volatile compounds included : citral or geranial ; myercene ; 2-propanone ; 3buten -2-ol ; 2-methyl ; 1,3,6-octatriene ; 5-heptan-2-one ; 3,7,-dimethyl ; 6 methyl ;1-1dimethyl ;1-3-methylidene ; 2-vinyle cyclohexane ; linalool oxide ; citronellal ; octanal,7-hydroxy-3,7-dimethyl, Delta (7) methanone 2; 2undecanone ; dehydro-Myrcenol ; nerol ; 2-nonyonic acid ; trans Graniol ; 6dodecanone ; Butanoic acid , 3-hydroxy-3-methyl ; Ethenyl-Cyclo hexane ; methyl ester of (Z) -2-Butanoic acid ; and Decadienal . The essential oil was identified by Gas Chromatography - Mass spectroscopy instrument ( HP 5890 SERIES II PLUS ), sample size of 0.5 micro liter, on oven temperature adjusted to $\left(60{ }^{\circ} \mathrm{C}-200{ }^{\circ} \mathrm{C}\right)$ in program rate of $3{ }^{\circ} \mathrm{C} / \mathrm{min}$. and HP CARBOWAX $20 \mathrm{M}$ Capillary colmn ( Hewlett Packrd, $50 \mathrm{M}$ length, $0.2 \mathrm{MM}$ interior diameter , $0.33 \mathrm{MM}$ film thickness ). Other analysis conditions included : Helium as Carrier Gas ( Flow rate $=1 \mathrm{ml} / \mathrm{min}$. , split ratio $=100: 1$ and attenuation $=3$ ), FID and TIC detectors ( injection port temp $=150{ }^{\circ} \mathrm{C} \&$ detector temperature $=250^{\circ} \mathrm{C}$ ), MS ionization voltage $=70 \mathrm{ev}$, atart - atop masses $=20-550 \mathrm{AMU}$ and Electron multiplier voltage $=1800 \mathrm{ev}$. 


\section{RESULTS AND DISCUSSION}

1. Inhibitory effect of lemon grass and rhubarb organic solvent extracts on mycelial growth of two fungi pathogenic to pothos:

Data presented in Table ( 1 ) demonstrate that organic solvent extracts of lemon grass leaves and rhubarb roots could inhibit mycelial growth of $F$. solani and $R$. solani , two fungi pathogenic to pothos plants causing root and stem rot diseases. Whereas, no antifungal effect was detected regarding the two fungi when sterilized distilled water was used ( control treatment) as well as in case of $F$. solani only using ethyl acetate extract of lemon grass . Moreover, the aforementioned two extracts varied in their effectiveness according to kind of the organic solvent tested. In this regards, ehanolic extracts were the most effective antifungal inhibitors tested affecting mycelial growth of the two pathogens, contrarily, those extracted with ethyl acetate were the least. In general, reduction in mycelial growth of the two fungi was less than $50 \%$ with superiority as for lemon grass extracts than those of rhubarb ones particularly with $F$. solani compared with the other fungus tested. However, reverse result was realized when ethyl acetate extracts were applied in case of $F$. solani since rhubarb proved to be more efficient than lemon grass one. Some medicinal plants supported their activities as sources of antifungal substances ( Ali , 1999). Positive efficiency of lemon grass organic solvent extract on mycelial growth inhibition of $F$. solani and $R$. solani causing soilborne fungal diseases of various hosts such as Cassia fistula (an ornamental tree ) in Egypt was reported (Halawa, 2004). Also, the effect of organic solvent extracts of rhubarb roots was reported (Radwan, 2001 ). Differences in the efficacies of lemon grass or rhubarb extracts might be ascribed to the kind of organic solvent used or variation in concentration and composition of the extracted antifungal toxic compounds . Several investigators confirmed such findings in respect to the effect of different extracts against various fungi ( Ismail , et al. , 1989 and Oasem \& Abo Blan , 1996 ) .

Table ( 1 ) : Inhibitory effect of lemon grass ( leaves ) and rhubarb (roots) on mycelial growth of the two fungi pathogenic to pothos plants,

\begin{tabular}{|c|c|c|c|c|c|c|c|c|}
\hline \multirow{3}{*}{ Extracts of } & \multicolumn{8}{|c|}{ Percentages of Inhibition } \\
\hline & \multicolumn{4}{|c|}{ Fusarium solani } & \multicolumn{4}{|c|}{ Rhizoctonia solani } \\
\hline & $A^{*}$ & B & C & D & $A^{*}$ & B & C & D \\
\hline \multirow{2}{*}{ Lemon grass } & 44.89 & 43.44 & 000 & \multirow[t]{2}{*}{000} & 33.78 & 28.78 & 5.00 & \multirow[t]{2}{*}{000} \\
\hline & \pm 2.2 & \pm 1.7 & & & \pm 3.6 & \pm 1.5 & \pm 0.9 & \\
\hline \multirow{2}{*}{ Rhubarb } & 30.60 & 26.40 & 2.17 & \multirow[t]{2}{*}{000} & 28.75 & 22.50 & 3.23 & \multirow[t]{2}{*}{000} \\
\hline & \pm 1.6 & \pm 0.7 & \pm 0.4 & & \pm 2.1 & \pm 3.3 & \pm 1.1 & \\
\hline Contro ( solvent only ) & 0.0 & 0.0 & 0.0 & 0.0 & 0.0 & 0.0 & 0.0 & 0.0 \\
\hline
\end{tabular}

${ }^{*} \mathrm{~A}, \mathrm{~B}, \mathrm{C}$ and D refer to ethanol, hexan, ethyl actate and control, respectively .

2. Inhibitory effect of different concentrations of lemon grass essential oil on mycelial growth of two fungi pathogenic to pothos.

Eight concentrations of lemon grass essential oil were experimented to determine their antifungal inhibitory effect on mycelial growth of $F$. solani and 
R.solani pathogenic to pothos plants and results of reduction in mycelial growth ( \% ) relative to control were recorded ( Table , 2 ).

Data in Table ( 2 ) and illustrated in Figs. ( 1 \& 2 ) indicate that all concens. tested $(2.5-60.0 \%)$ of lemon grass essential oil evidently inhibited mycelial growth of the two fungi under investigation. Besides, percentages of reduction in mycelial growth of these fungi relative to their control treatments ( discs with sesame oil only) positively increased by increasing the concentration used. However, concens. of $20-60 \%$ completely prevented mycelial growth of the two fungi in addition to the concen. of $10 \%$ in case of $F$. solani only. The antifungal toxic effect of several essential oils including lemon grass one on the in vitro mycelial growth of F. solani and R.solani were reported ( Patinaik et al. , 1996 ; El Shazly, 2000 and Halawa, 2004 ). The antifungal activity of essential oils might be due to their capabilities to cause damage on structure and function of the fungal cell wall in addition to disturbing the physiology of the enzymatic bioactivity. Also, the fungal growth damages might be ascribed to the abilities of essential oils to penetrate into the fungal cells causing alternation in metabolism by their mutagenic activities as well as inhibition in the fungal detoxification enzymes of the toxic antifungal oil substance (Zambonelli et al., 1996) . Moreover, the essential may be able to affect respiration of the fungal cells ( oxygen uptake) as reported by Inouye et al. ( 1988 ) .

Table ( 2 ) : Effect of different concentrations of lemon grass essential oil on mycelial growth of two fungi pathogenic to pothos :

\begin{tabular}{|c|c|c|}
\hline Essential oil & \multicolumn{2}{|c|}{ Percentages of Inhibition } \\
\cline { 2 - 3 } concentrations (\%) & Fusarium solani & Rhizoctonia solani \\
\hline $\mathbf{6 0}$ & 100.0 & 100.0 \\
\hline $\mathbf{5 0}$ & 100.0 & 100.0 \\
\hline $\mathbf{4 0}$ & 100.0 & 100.0 \\
\hline $\mathbf{3 0}$ & 100.0 & 100.0 \\
\hline $\mathbf{2 0}$ & 100.0 & 100.0 \\
\hline $\mathbf{1 0}$ & 100.0 & 89.1 \\
\hline $\mathbf{5}$ & 83.3 & 58.9 \\
\hline $\mathbf{2 . 5}$ & 66.7 & 42.6 \\
\hline $\mathbf{0}$ & 0.0 & 0.0 \\
\hline
\end{tabular}

3. Effect of lemon grass leaves and rhubarb roots ethanolic extracts used as root - dip treatment on percentages of pothos stem and root rots incidence under greenhouse conditions:

Data in ( Table , 3 )reveal that dipping root system of pothos cuttings separately in three concentrations of ethanolic extracts of lemon grass leaves or rhubarb roots for $15 \mathrm{~min}$. just before planting in pail infested with F.solani or $R$. solani evidently lowered stem and root rots incidence(\%)caused by these fungi compared with those of their controls (infested pail only).As for each fungus tested, all concens. lemon grass extract were more efficient than those of rhubarb ones. Also, positive relationship was realized between increasing cons. of each extract from $5 \%$ to $20 \%$ and increase in reduction 
regarding diseases incidence caused by either of the two fungi tested. In conclusion , the highest cons. tested (20\%) of the two extracts resulted in the lowest percentages of diseases incidence by ( $5 \%$ \&15\%) and (10\% \&20\%) concerning F.solani and $R$. solani, respectively ,relative to $40 \%$ and $60 \%$ diseases incidence of their controls (infested pail/ untreated cuttings ) .Soil borne fungal disease have been controlled for several years ago applying traditional methods and using the available substances for the management of such diseases, however, fungicides showed high superiority in this respect. On the other hand, fungicidal treatment was the only method used to control the diseases under investigation(El- Morsy,2000). Unfortunately, fungicides became unsafe means in respect to environmental pollution because of their toxic residuals. The successful effects of using lemon grass essential oil for controlling stem and root rots of pothos are in agreement with those reported by Agha(1992),Ali (1999) and Halawa(2004) who used this natural plant product in controlling soil borne fungal diseases on other hosts and recorded some success in this regards.

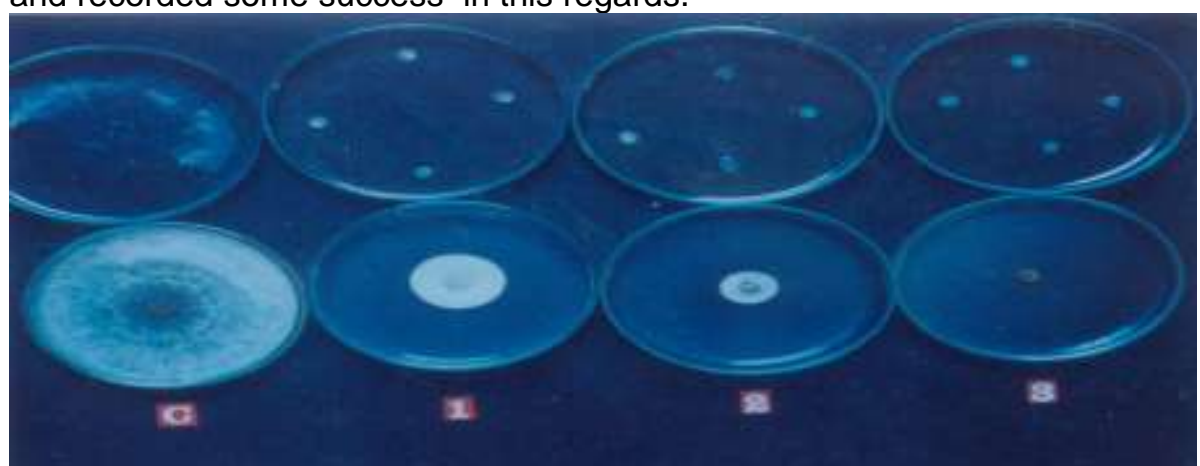

Fig . (1) : Showing the antifungal inhibitory effect of lemon grass essential at concens. Of $2.5 \%(1), 5.0 \%(2)$ and $10.0 \%$ (3) against mycelial growth of $F$. solani . Control at the left .

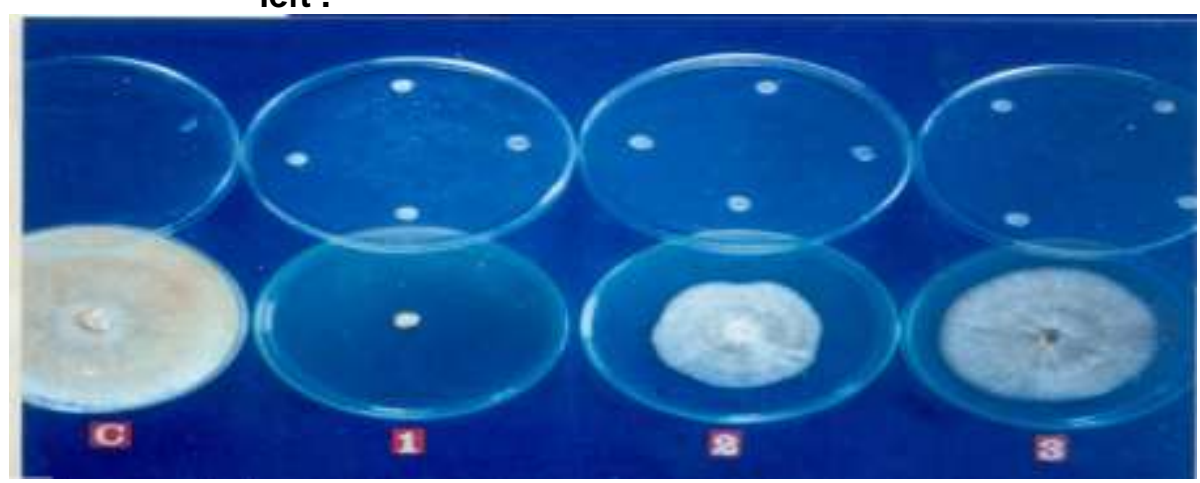

Fig. ( 2 ) : Showing the antifungal inhibitory effect of lemon grass essential at concens. Of $10.0 \%(1), 5.0 \%(2)$ and $2.5 \%$ (3) against mycelial growth of $R$. solani . Control at the left . 
Table (3): Effect of lemon grass leaves and rhubab roots ethanolic extracts ( 3 concens.)used as root - dip treatment for controlling root and stem rots caused by two fungi pathogens to pothos plants.

\begin{tabular}{|c|c|c|c|c|c|c|c|c|c|c|}
\hline \multirow{3}{*}{$\begin{array}{c}\text { Extract } \\
\text { of }\end{array}$} & \multicolumn{10}{|c|}{ Disease incidence ( \%) } \\
\hline & \multicolumn{5}{|c|}{ F. solani } & \multicolumn{5}{|c|}{ R. solani } \\
\hline & $\mathbf{C}^{\star}$ & $5 \%$ & $10 \%$ & $20 \%$ & mean & $\mathbf{C}^{\star}$ & $5 \%$ & $10 \%$ & $20 \%$ & mean \\
\hline \begin{tabular}{|l|} 
Lemon \\
grass
\end{tabular} & $40 \%$ & 30.0 & 15.0 & 5.0 & 22.5 & 60.0 & 37.5 & 30.0 & 10.0 & 34.4 \\
\hline Rhubarb & $40 \%$ & 37.5 & 30.0 & 15.0 & 30.6 & 60.0 & 40.0 & 37.5 & 20.0 & 39.4 \\
\hline mean & 40.0 & 33.8 & 22.5 & 10.0 & & 60.0 & 38.8 & 33.8 & 15.0 & \\
\hline
\end{tabular}

L.S.D. at $5 \%$ for :

$\begin{array}{lll}\text { Fungi (F) } & =6.4 & \\ \text { Extracts (E) } & =0.8 & \text { (F) } \times(E)=1.1 \\ \text { Concentrations (C) }=4.3 & \text { (E) } X(C)=6.0 \\ \text { (F) } \times(C)=6.0\end{array}$

$(F) \times(E) \times(C)=8.5$

(E) $X(C)=6.0$

4. Physical and chemical characteristics and volatile matter composition of lemon grass essential oil:

Physical and chemical characteristics:

According to the available standard essential compounds, four important physical and chemical properties of lemon grass volatile oil were identified, subsequently determined to assess their values and applications (Table,4).

Data in Table (4) demonstrate that specific gravity, optical rotation , refraction index and acid number of lemon grass essential oil recorded values of $0.89,-1.6,1.4875$ and 8.3 , respectively. However, value of gravity determined indicate that the essential oil of lemon grass contains various components belong to deferent chemical classes since its value occupied between ( $\leq 0.8)$ and $(\geq 1.0)$, whereas the optical rotation represent an important criterion of oil purity (Guenther,1961). On the other hand, the high value of acid number suggests that lemon grass oil inclines to low hydrolysis.

Table (4): Determination of physical and chemical constants of the lemon grass essential oil of Cymbopogon citratus.

\begin{tabular}{|l|c|}
\hline \multicolumn{1}{|c|}{ CONSTANT } & Measurements \\
\hline Specific gravity At $\mathbf{2 0} 0^{\circ} \mathrm{C}$ & 0.89 \\
\hline Optical rotation At $\mathbf{3 0}{ }^{\circ} \mathrm{C}$ & -1.6 \\
\hline Refractive index At $\mathbf{2 0} \mathrm{C}$ & 1.4875 \\
\hline Acid Number & 8.3 \\
\hline
\end{tabular}

5. Identification of the major compounds of lemon grass essential oil:

Volatile matter composition of the oil under study represented $100 \%$ of the total composition oil of $C$. citratus. Oil of $C$. citratus contained mainly (ZCitral and E- Citral) Geranial $(77 \%)$ as a major component followed by Myrecene (6.5\%). Other constitutions included 2 methyl 1,3,6- octatriene, 3,7,-dimethyl-; cis-ocimen; 5-Hepten-2-one6 Methyl;1,1dimethyl-3methylidene-2-vinylcyclo-hexane; trans linalool oxide; citronellal; octanal,7- 
OH-3,7dimethyl-; linalool; Delta.(7)-methenone-2; Dihydro myrcenol; 2 ndecanone; Nerol;2-Nonyonic acid; trans-Geraniol; 6- Dodecanone, Butanoicacid, 3-hydroxy-3methyl; Ethenyl-cyclohexane;methyl ester of cis-2butanoic acid ; and Decadienal occurred as trace compounds. Results of composition of the investigated essential oil were in accordance with other reports, Ragjeswara et al ( 1996) and Harridy et al ( 2001).

6- Inhibitory effect of the main components of lemon grass oil on mycelial growth of the two fungi teasted:

Data in Table (5) and illustrated in fig.(3) indicate that citral at concentration of $2.5 \%$ completely prevented mycelial growth of both $F$. solani and $R$. solani in PDA plates in lab. Whereas, the same concentration of myrecene was less effective as it recorded percentages of inhibition by $40 \%$ and $28.6 \% \%$ for the aforementioned two fungi , respectively.

Table (5): Direct effect of $2.5 \%$ concen. of Citral \& Myrecene, as , the major components of lemon grass essential oil on mycelial growth of the two fungi pathogenic to pothos plants.

\begin{tabular}{|l|c|c|}
\hline \multirow{2}{*}{$\begin{array}{l}\text { Major Component of lemon } \\
\text { grass oil }\end{array}$} & \multicolumn{2}{|c|}{ Inhibition\% } \\
\hline Citral & 100 & R. solani \\
\hline Myrecene & 40 & 100 \\
\hline Control & 0.0 & 28.6 \\
\hline
\end{tabular}

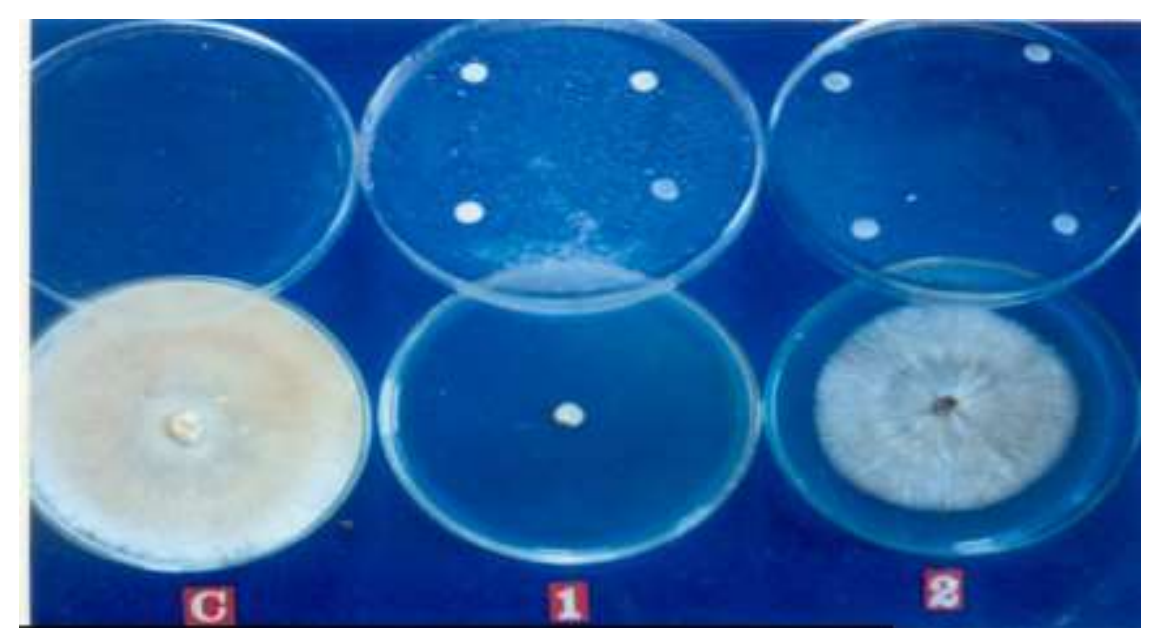

Fig(5): Anti fungal activity of plant essential oil composition (1) Citral and Myrecene (2) (2.5\%) against $R$. solani .

These results were in complete accordance with those reported by Radwan ,(2001). 


\section{REFERENCES}

Agha, M.S. ,1992.Studies on antifungal agents in certain ornamental , medicinal and aromatic plants with special reference to control seedlings damping - off disease of sesame. Egypt. J.Appl. Sci. 7(1): 104-114.

Ali,A.A. ,1999. Studies on some medicinal plants as a source of antifungal substances in North African .M.Sc. Thesis, Inst. of of African Res. and Studies, Cairo Univ.

Ansari,M.M. ,1995. Control of sheath blight of rice by plant extracts. Indian Phytopathol., 8: (3),268-270.

Ashrafuzzaman, M.H.; A.R.Khan and A.R. Howlider ,1990. In Vitro effect of lemon grass oil and crude extracts of some plants on Rhizoctonia solani. Bangladesh j. of p. p., $6:(1-2), 17-18$.

Baratta, M.T.; H.J.D. Dorman; S.G.Deans; A.C Figueiredo; J.G.Barroso and G. Ruberto,1998. Anti-microbial and anti- oxidant properties of some commercial essential oil. Flavour and Fragrance J.,13: (4),235-244.

Brock,D.T. and K.M. Brock, 1973. Basic microbiology with applications .Prentice Hall,Inc..Englewood Cliffs, New Jersy USA.

Chase, A.R., 1987. Compendium of ornamental foliage plant diseases. $1^{\text {th. }}$ ed. APS Press, St. Paul, .Minneapolis, MN , USA.

Dubey,R.C.,1991.fungicidal effect of essential oils of three higher plants on sclerotia of Macrophomina phaseolina Indian phytopathol.,44(2):241244.

EL- Morsy, S.A. ,2000 .Studies on some soil borne pathogens causing root rot to some ornamental plants. Ph.D.Thesis , Fac.Agric. Cairo Univ., Cairo, Egypt.

El- Shazly, A.M.A.,2000. Antifungal activity of some essential oils on fungi causing damping off diseases of maize . Al Azhar J. Agric. Res., 31 (6) : 95-107.

Guenther,F. ,1961. Essential oil Nostr and Com. Inc. Princeton, New Jersy, New York.

Halawa,A.E.A.,2004.Pathological studies on some soil borne fungi attacking some of ornamental trees in Egypt . Ph.D.Thesis , Fac.Agric. (Moshtohor),Zagazig.

Harridy, I. M. A.; S. G. I.Soliman and M. A. T.Amara, 2001. Physiological, chemical and biological studies on lemon grass Cmbopogan citralus (DC) Stapf in response to diazotrophic bacteria.J. Agric. Sci. Mansoura Univ. 26 (10): $6131-6154$.

Inouye,S.; M.Watanable; Y.Nishiyama; K.Takeo; M.Akao and H.Yamaguchi,1988. Antisporulation and respiration effects of essential oils on filamentous fungi. Mycoses, 41: 403- 410

Ismail,I.M.K.;A.A.M.Salama; M.I.A. Ali and S.A.E.Out,1989. Bioassay of Eucalyptus rostorata leaf extractives on Sclerotium cepivorum Berk. Egypt. J. Bot., 32(12); 109-126. 
Kshirsagar,M.K.and A.R.Mehta,1972. Survey of ferns in Gujart State (India) for presence of antibacterial substances of ferns. Planta Medica, 22(4): 386-390.

Oasem,J.R.and H.A.AbuBlan,1996. Fungicide activity of some common weed extracts against different plant pathogenic fungi . J. Phytopathology, 144: 157-161.

Patinaik, S.;V.R.Subramanyam and C.Kole,1996. Antibacterial and antifungal activity of essential oils in vitro . Microbios ,86 (349): 237-246 (c. f. Rev. Pl. Pathol., 76(3): 233,1997).

Radwan,Olfat, A. S. M.,2001. Biochemical studies on some plant extracts as pesticides. Ph.D. Thesis, Fac. Agric., Cairo Univ., Cairo,Egypt.

Ragjeswara Rao,B.R.; P.N.Kaul and A.K.Bhatta charya, 1996.Yield and chemical composition of the essential oils of three Cymbopogon species suffering from iron chlorosis. Flavour and Fragrance J.,(11)289-293.

Raju, M.R.B.; V.Pal and I. Jalali, 2009. Ecofriendly friendly approach for the management of Bacterial soft rot of Radish seed crop. Journal of Eco friendly Agriculture, 4 (1):65-68.

Shimoni, M.; R. Reuvent, and U. Ravid, 1993. Growth inhibition of plant pathogenic fungi by essential oils. Hassadeh, 74: (3),306-308.

Soliman, K.M. and R. I. Badeaa, 2002. Effect of oil extracted from some medicinal plants on different myco-toxigenic fungi. Food Chem Toxicol. 40:1669-1675.

Valarini, P.J.; Rts. Frighetto; C.A.Spadotto, 1996. Potential of the medicinal herbage Cymbopogon citrates for the control of pathogens and weeds in irrigated crop. Cientifica, Jaboticabal, 24: (1), 199-14.

Wood, M.;Schollenbeger,M.and Zamarski,C. (1997). Effect of extracts four medicinal plants, on growth of selected fungi and bacteria. Annals of Warsaw Agric Niversity, SGGW, Horticulture.

Yang, X.; M. Xingxia; Y. Lijun; Y.Dazhao; Q.Yixin andN. Hanwen, (2009). Efficacy of Rheum officinale liquid formulation on cucumber powdery mildew. Crop Protection, Vol. 28, Issue 12, 1031-1035.

Zambonelli, A.;A.Bianchi and A.Albasini,1996.Effect of essential oils on phytopathogenic fungi in vitro. Phytopathology, 86: 491-494. 


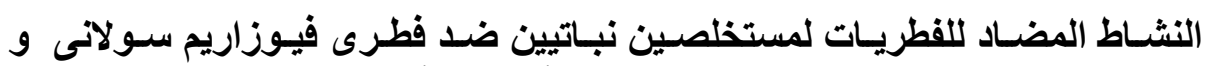

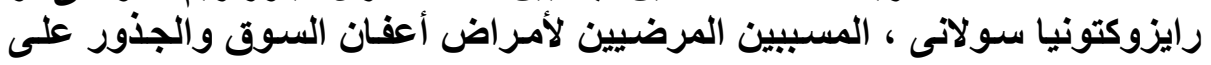

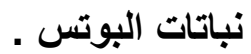

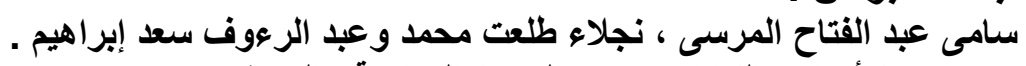

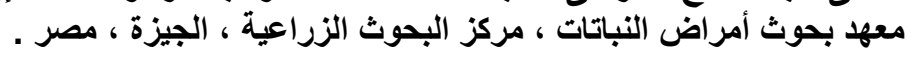

كانت المستحلصات بالدذيبات العصوية لأوراق حشيشة الليمون أكثر فعالية عن تلك الكئل الخاصـة

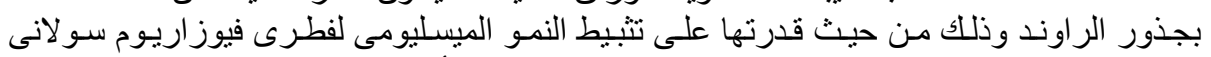

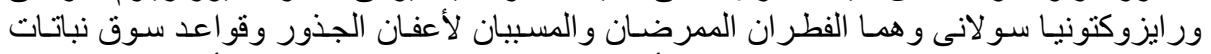
البوتس ـ ولقد كانت المستخلصات الإيثانولية أفضل من تلإن المستخلصة بالهكسان الهـان أو خلات الإيثايل

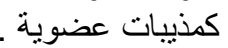

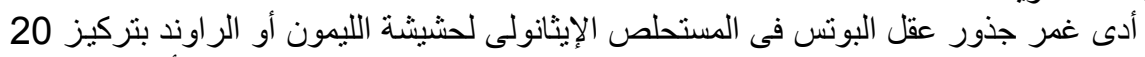

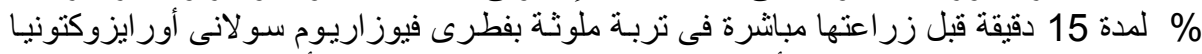

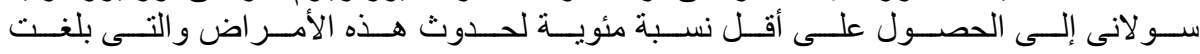

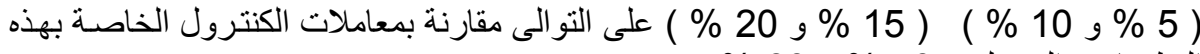
الفطريات و التى بلغت 40 \% و 60 \% \% 15 \%

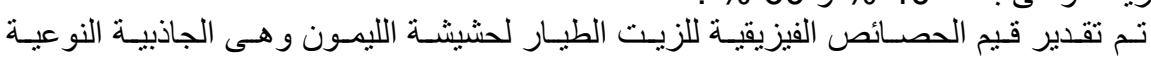

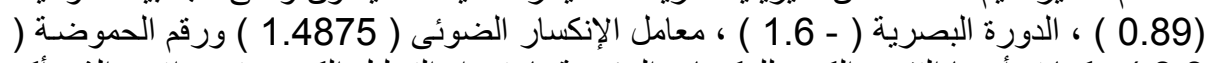

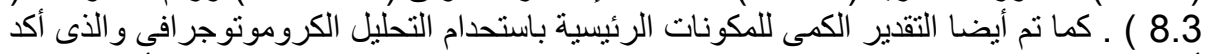

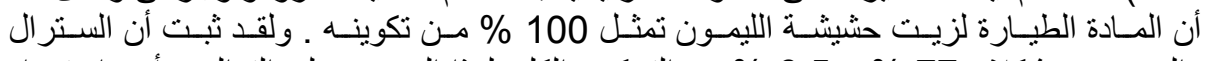

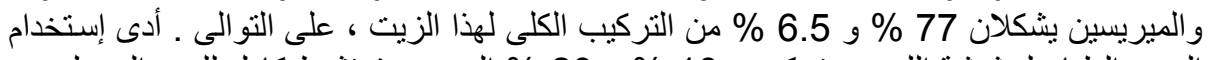

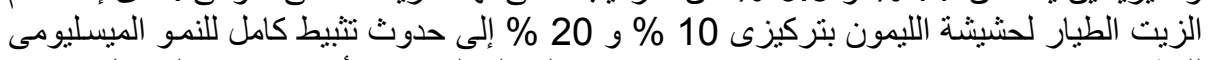

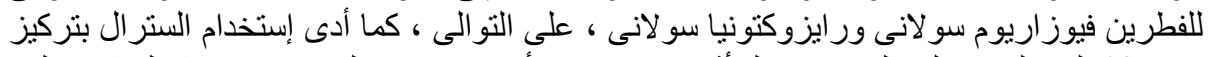

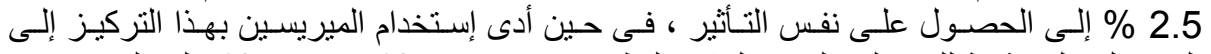

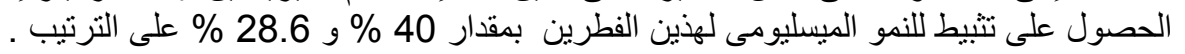

كلية الزراعة - جامعة المنصورة مركز البحوث الزراعية
قام بتحكيم البحث

أ.د / عام إسر محمد نور الدين شبانه

أ.د / أد / عبد الودود زحمى نور عاشور 